\title{
Integrated management approaches for controlling root rot of bael caused by Fusarium solani
}

\author{
M. Singh ${ }^{1}$, Sushil Sharma ${ }^{2 *}$ and Mukesh Kumar $^{3}$ \\ ${ }^{1}$ Department of Plant Pathology, College of Agriculture, Chaudhary Charan Singh Haryana Agricultural \\ University, Hisar - 125004 (Haryana), INDIA \\ ${ }^{2}$ Chaudhary Charan Singh Haryana Agricultural University, Regional Research Station, Bawal - 123501(Haryana), \\ INDIA \\ ${ }^{3}$ Chaudhary Charan Singh Haryana Agricultural University, Krishi Vigyan Kendra, Bawal-123501 ( Haryana), INDIA \\ *Corresponding author. E-mail: skvrrsbawal@rediffmail.com
}

Received: September 27, 2015; Revised received: February 19, 2016; Accepted: May 23, 2016

\begin{abstract}
An experiment was carried out to find out the effective management practices to control the recently recorded pathogen (Fusarium solani) inciting root rot disease in Bael. Rampant incidence due to this pathogen is resulting in excess damage and reduction in acreage. Out of six fungicides screened in vitro, Topsin-M and Bavistin stood at first place in inhibiting the mycelial growth of $F$. solani. Topsin-M showed $100 \%$ inhibition at 50 ppm concentration whereas Bavistin showed $100 \%$ inhibition at $150 \mathrm{ppm}$ concentration. Bavistin and Topsin-M as seed dressers effectively protected pre and post emergence seedlings mortality to the tune of 68.75 and $70.95 \% ; 65.00$ and $67.54 \%$, respectively. Pre-sowing drenching of soil with Bavistin $(0.4 \%)$ reduced the pre-emergence mortality from 26.50 to $8.25 \%$ and post-emergence mortality from 39.00 to $16.25 \%$. The integration of seed treatment and pre -sowing drenching resulted in $72.51 \%$ control of pre emergence mortality and $82.92 \%$ control of post emergence mortality. In dual culture method, maximum inhibition of mycelial growth was recorded with Trichoderma harzianum $(72.18 \%)$ followed by $T$. viride $(67.70 \%)$. Glomus mosseae in combination with $T$. harzianum was found very effective against $F$. solani under screen house conditions as minimum pre emergence mortality $(10.00 \%)$ and post emergence mortality (13.25\%) against control where the values were $27.25 \%$ and $40.25 \%$, respectively. The studies and results compiled here in provide an explanation for the potential of selected fungicides and antagonists in the control of bael root rot disease.
\end{abstract}

Keywords: Aegle marmelos, Bael, Biocontrol agents, Mycorrhiza, Seed treatment, Soil drenching

\section{INTRODUCTION}

Bael (Aegle marmelos Correa) is very popular indigenous fruit of India. It is also known by other vernacular names like Bael, bili, bilva, belo, sriphal and Bengal quince (John and Stevenson, 1979). The Bael tree has found mention in mythological treatises and Indian Pharmacopoeia. It is grown near temple of the Lord Shiva in India. According to Hindu customs, the leaves of the tree are considered sacred and offered to the Lord Shiva, Its medicinal properties have been dealt with in the 'Charaka Samhita', an early medical treatise in Sanskrit (Aiyer, 1956). The importance of Bael fruit lies in its curative properties, which make the tree one of the most useful medicinal plants of India (Kirtikar and Basu, 1935). Though, there are scattered reports on its foliar and fruit diseases but recently heavy decline in Bael tree due to Fusarium solani (Mart.) Sacc have been recorded in different parts of the country especially in Haryana and Rajasthan (Anonymous, 2011; Sharma and Gaur, 2014). The strategy of chemical control of plant disease is based on the principle of immobilizing the pathogen so that it does not interact with the host to cause disease (Sinha et al., 1988). Integration of biological and chemical control seems to be a promising way of controlling many pathogens with minimum interference in the biological equilibrium in soil (Kumar et al., 2011). Root rot of Bael has become a potential threat since 2007 in Haryana. Barring report of occurrence during 2014 , there is no study available in the literature on any aspect including its management. An effort was therefore made to find out the effective management approaches to curtail root rot disease.

\section{MATERIALS AND METHODS}

In vitro screening of fungicides: Six different fungicides were screened by poisoned food technique as described by Palmiter and Keith (1937) using PDA medium. Stock solutions of Captan (Captaf), Bavistin (Carbendazim), Beam (Tricyclazole), Mancozeb (Indofil M-45), Topsin-M (Thiophanate methyl) and Thiram (Thiram) were prepared having 2000 ppm (a.i. basis) concentration using double distilled sterilized water. The solution was further diluted with the help of 
double distilled sterilized water for desired strength i.e. 50, 100, 150 \& 200 ppm concentration. Doublestrength PDA medium (400 g peeled potato extract, 40 $\mathrm{g}$ dextrose and $40 \mathrm{~g}$ agar-agar per litre) was prepared and sterilized in autoclave for 20 minutes at $15 \mathrm{lbs}$ inch -2 pressure. Seventy-five $\mathrm{ml}$ of medium and equal amount of fungicidal solution of each concentration were taken in sterilized conical flask and mixed together under aseptic condition. Finally the mixture gave 50,100, 150 and $200 \mathrm{ppm}$ concentration. The medium containing required dose of fungicide was poured in five sterilized petriplates and was kept for solidification. Each petriplate was inoculated with 5 mm mycelia disc in the centre. A separate check without fungicide application for each treatment was also maintained. Per cent growth inhibition of $F$. solani at different doses was calculated on the basis of decrease in area of mycelia growth with respect to check using the following formula:

Inhibition $(\%)=\frac{\mathrm{C}-\mathrm{T}}{\mathrm{C}} \times 100$

Where, C- stands for check and T- stands for treatment.

In vivo evaluation of fungicides as seed dressers: To find out the effective fungicides for the control of root rot of Bael, different fungicides viz., Captan, Bavistin, Beam, Indofil M-45, Topsin-M and Thiram were tried as seed dressers (Kumar et al., 2011). Two fungicides Bavistin (Carbendazim), Topsin-M (Thiophanate methyl) found promising under laboratory conditions were further evaluated under screen house conditions at three concentrations i.e. $0.1,0.2$ and $0.4 \%$ through seed treatment. The doses were used on formulation basis for treating the seed of Bael@ $2 \mathrm{~g} \mathrm{~kg}^{-1}$ of seed. About 4-5 drops of water were first added to the required quantity of seed, thoroughly shaken to moisten the entire seed coat and then required amount of fungicides was added. The flask containing seed and fungicide was shaken vigorously so as to enable uniform coverage of seed coat by fungicide. The treated seeds

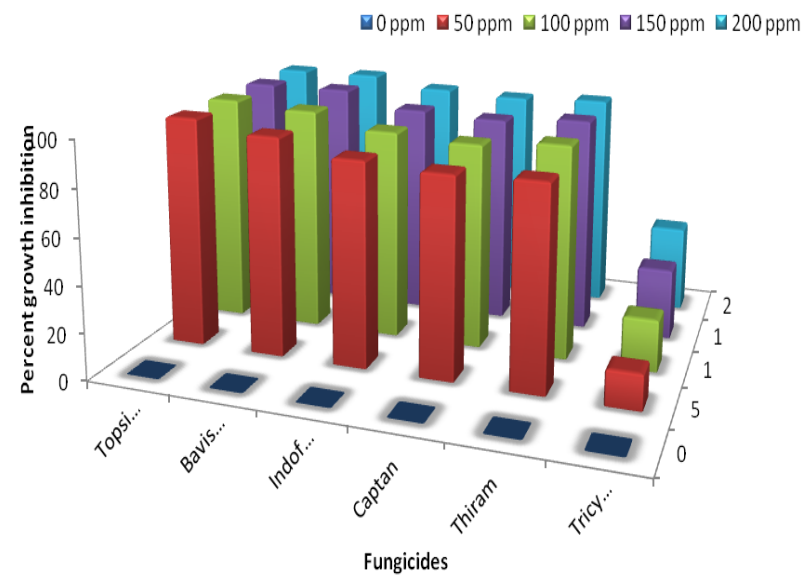

Fig. 1. Effect of different concentrations of fungitoxicants inhibition of radial growth of $F$. solani in Bael. were sown in sterilized $F$. solani inoculated soil. In control, no fungicide was applied. Ten seeds in each pot were sown. Four replications for each treatment were maintained. The data on seedling pre-emergence and post-emergence mortality was recorded 10 and 45 days after sowing and \% disease control was calculated using following formula.

Disease control $(\%)=$ D.I. in control - D.I. in treatment/D.I. in control x 100

Where, D.I. - stands for disease incidence

In vivo evaluation of fungicides as soil drench: Two fungicides Bavistin (carbendazim), Topsin-M (thiophanate methyl) found promising under laboratory conditions were further evaluated under screen house conditions at three concentrations i.e. $0.1,0.2$ and $0.4 \%$ through drenching of soil adopting the method of Kumar et al., (2011). Ten untreated seed were sown in each pot. The pots were irrigated regularly. The data on pre-emergence and post-emergence were recorded 20 and 50 days after sowing. The \% disease control was also calculated by the formula given in the previous experiment.

In vivo evaluation of fungicides as combination of both seed dresser and soil drench: Two fungicides Bavistin (Carbendazim), Topsin-M (Thiophanate methyl) found promising under laboratory conditions were further evaluated under screen house conditions at three concentrations i.e. $0.1,0.2$ and $0.4 \%$ through combination of seed treatment and soil drenching following the method of Kumar et al., (2011).

In vitro evaluation of fungal antagonists: Antagonistic fungi viz., Trichoderma viride and T. harzianum isolated from rhizosphere of crops were obtained from Department of Plant Pathology, CCS HAU, Hisar. These antagonistic fungi were screened for their efficacy in suppressing the growth of $F$. solani by dual culture technique (Morton and Stroube, 1955). Mycelial discs (5 $\mathrm{mm}$ diameter) were taken both from actively growing culture of $F$. solani (10 days old) and Trichoderma spp. culture (7 days old) and placed in petri plates (90 mm diameter) containing $20 \mathrm{ml}$ steril-

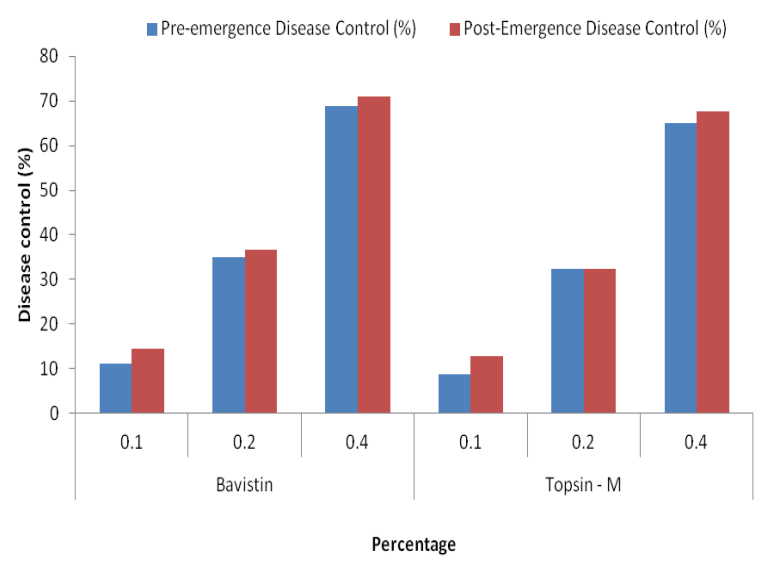

Fig. 2. Effect of seed treatment with promising fungitoxicants on the incidence of seedling mortality due to F. solani in Bael. 


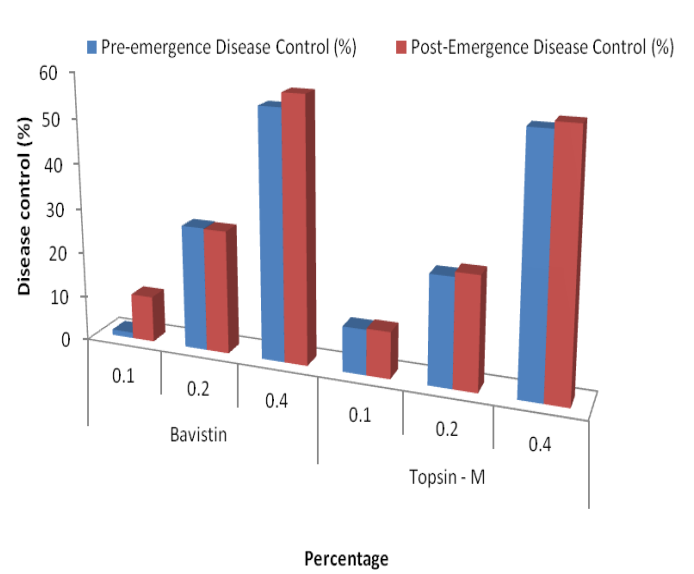

Fig. 3. Effect of pre-sowing drenching of soil on the incidence of seedling mortality due to F. solani in Bael under screen house conditions.

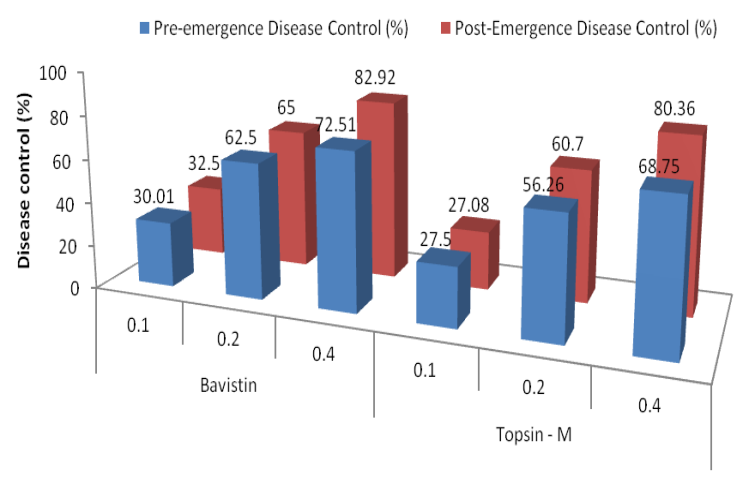

Percentage

Fig. 4. Effect of seed treatment and soil drenching on the incidence of seedling mortality due to F. solani in Bael under screen house conditions.

ized PDA. A bit of pathogen was kept at one side of Petri plate and bit of antagonist was placed on other side, both having equal distances from the edges of Petri plate. Control plates without the disc of antagonist i.e. inoculated only with the pathogen was kept for comparison. Each treatment had four replications and was maintained along with control. Inoculated plates were incubated at $25 \pm 2{ }^{\circ} \mathrm{C}$ in BOD incubator. Observations on radial growth of the pathogen both in treatment as well as in control plates were recorded after every 24 hours of inoculation with metric scale $(\mathrm{mm})$ till the complete coverage of pathogen in control plates. The \% inhibition of mycelium growth over control was calculated by using the formula (Vincent, 1947).

In vitro evaluation of bacterial antagonist: Pseudomonas fluorescens, Pseudomonas maltophila and $\mathrm{Ba}$ cillus subtilis strain were obtained from the Department of Microbiology, CCS HAU, Hisar. Pseudomonas fluorescens isolate was multiplied on King's B medium agar plates (King et al., 1954). The antagonists were evaluated as per method of Kumar et al.,

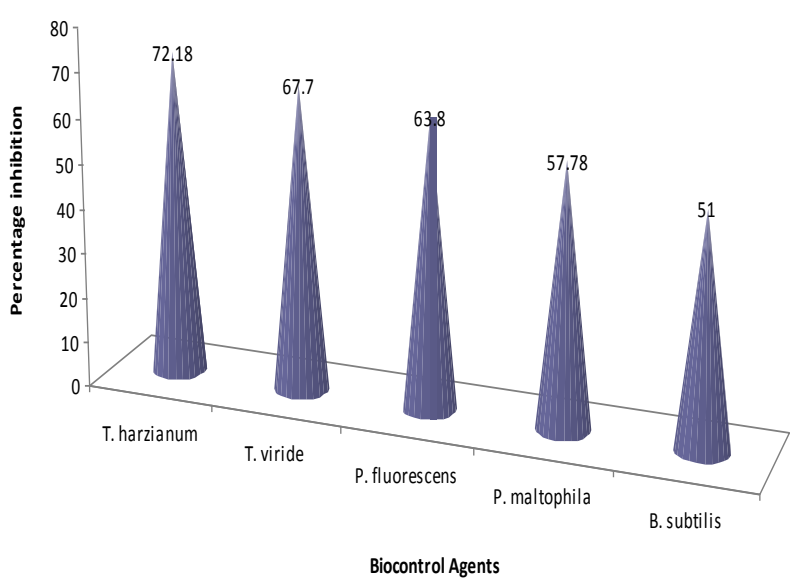

Fig. 5. Effect of bio-control agents inhibition of radial growth of F. solani using dual plate technique.

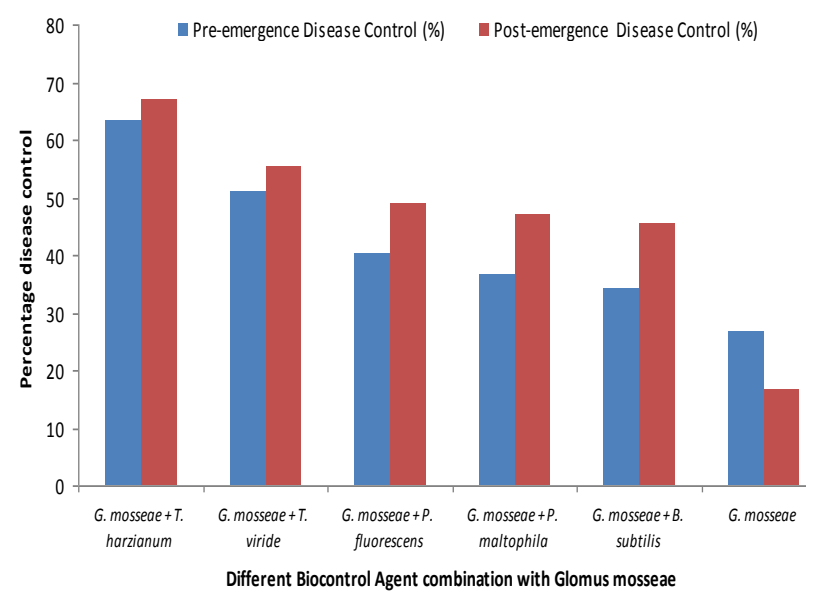

Fig. 6. Effect of bio-control agents on incidence of seedling mortality due to F. solani in Bael under screen house conditions.

(2012). One disc of medium with bacterium $(5 \mathrm{~mm}$ diameter) was taken and put into a test tube containing $10 \mathrm{ml}$ of sterilized water and shaken for 15 minutes. Twenty $\mathrm{ml}$ sterilized potato dextrose agar medium was poured in each sterilized petri plate ( $90 \mathrm{~mm}$ diameter). The bacterial isolate was streaked at periphery of petri plates plated with PDA medium and mycelial disc (5mm diameter) of 7 days old fresh-culture of $F$. solani was placed at the center of Petri plate. Each treatment was conducted in quadruplicate along with control for comparison. The inoculated plates were incubated at $27 \pm 1^{\circ} \mathrm{C}$ in BOD incubator. Observations on radial growth of the pathogen both in treatment as well as in control plates were recorded after every 24 hours of inoculation with metric scale $(\mathrm{mm})$ till the complete coverage of pathogen in control plates. The \% inhibition of mycelium growth over control was calculated by using the formula given by Vincent (1947).

In vivo evaluation of biocontrol agents: The experiment was conducted in earthen pots having $5 \mathrm{~kg}$ sterilized soil. The biocontrol agents viz. P. fluorescens, $P$. maltophilia and $B$. subtilis along with the pathogen $(R$. 
bataticola) were grown in nutrient broth and PDA, respectively. The methodology of Kumar et al., (2012) was followed for inoculation. For each treatment, the seeds were surface sterilized with $2 \%$ sodium hypochlorite solution for half a minute and then washed 2 -3 times with sterilized distilled water. The seeds were coated with slurry of mycelial mat of the pathogen. The required quantity of mycelial mat (15 g/ $\mathrm{kg}$ seed) was taken in a container and sufficient quantity of water was added to make it as a thin paste but not too watery. The seed was mixed thoroughly with paste for even distribution of the pathogen. Suitable sticker carboxy methyl cellulose $(0.1 \%)$ was added for better adherence of pathogen to the seed. The seed was dried in shade before sowing. In case of inoculation with PGPRs + pathogen, the seeds were treated first with bio-agents (dipping in suspension of $1 \times 10^{8} \mathrm{cfu} / \mathrm{ml}$ for half an hour) and air dried followed by coating with mycelial mat of pathogen and again air dried to ensure the infection. For mycorrhizal inoculations, the inoculum (Soil + rootlets) of Glomus mosseae was obtained from the Department of Plant Pathology. The soil in pots was inoculated with mycorrhizal culture @ $10 \mathrm{~g} /$ pot and the inoculum was placed just below the sowing of seeds (Margaret et al., 2011). Rest of the procedure, from soil infestation to recording of data was same as in previous experiment. The seeds coated with only $F$. solani served as control. After seed treatment, 15 seeds were sown in each pot with three replications. The pots were watered regularly. The observations on disease incidence were recorded as pre-emergence and post emergence mortality after 7 and 30 days of sowing, respectively. Per cent disease control was calculated by using under mentioned formula:

$\%$ disease control $=$ Percent disease in control Percent disease in treatment/Percent disease in control X 100

Where, disease incidence stands for sum total of pre-emergence and post- emergence mortality

\section{RESULTS AND DISCUSSION}

In vitro screening of fungicides against $F$. solani : The basic approach before recommending chemical control against a particular disease is to screen the fungicides against pathogen under laboratory conditions. Several workers had screened number of fungicides against $F$. solani, the causal organism of root rot disease in several crop plants. Six fungitoxicants including systemic and non-systemic were screened for their toxicity against mycelial growth of $F$. solani by poisoned food technique. PDA medium was poisoned aseptically with fungicides at the rate of 50, 100, 150 and $200 \mathrm{ppm}$ (a.i. basis) separately. Radial growth of the mycelium was measured seven days after incubation. Data on \% inhibition of growth is depicted in Fig.1. It could be seen from the data that with the increase in concentration of fungicides, there was decrease in mycelial growth of the fungus thus resulting in increased inhibition. Amongst the various fungicides tested, Topsin-M was adjudged more effective as it showed $100 \%$ inhibition of mycelial growth even at 50 ppm followed by Bavistin where $100 \%$ inhibition in mycelial growth was observed at $150 \mathrm{ppm}$. The other fungicides in descending order of efficacy were Indofil M-45, Captan and Thiram. Tricyclazole was rated as least effective as the inhibition percentage was 37.8 at highest concentration tried. These results are in accordance with the earlier findings of Poddar et al., (2004) and Vatchev and Maneva (2012). Sharma et al., (2004) reported that mycelial growth of $F$. solani causing root rot of Khejri was completely inhibited at 50 and 100 ppm concentration of Bavistin and Topsin-M, respectively.

In vivo evaluation of fungicides as seed dressers: Out of six fungicides, the best two fungicides Bavistin (carbendazim) and Topsin-M (thiophanate methyl) were taken at different concentrations $(0.1 \%, 0.2 \%$ and $0.4 \%$ ) and evaluated against $F$. solani causing the pre and post emergence mortality. The data presented in Fig. 2 showed that the recession in the pre and postemergence mortality and enhanced disease control was noted with increased concentration of fungicide. Maximum disease control in pre $(68.75 \%)$ and post $(70.95 \%)$ emergence was observed in seed treatment with Bavistin whereas the figures of pre and post emergence motality were 65.00 and $67.54 \%$, respectively when seed treatment was done with Topsin - M at $0.4 \%$ concentration. Both the fungicides were approximately equally effective against $F$. solani under screen house conditions. Seed treatment with Bavistin and Topsin $\mathrm{M}$ alone or in combination with other fungicides controlled the various isolates of $F$. solani from teak and soybean (Ramesh, 2002; Khodke and Raut, 2010).

In vivo evaluation of fungicides as soil drench: Two fungicides Bavistin (carbendazim) and Topsin-M (thiophanate methyl), found promising under laboratory conditions were further evaluated under screen house conditions at three concentrations i.e. $0.1,0.2$ and $0.4 \%$ through soil drenching. The data presented in Fig. 3 depicted that the pre and post-emergence mortality decreased with the increase in concentration of fungicide. Maximum disease control of pre $(55.00 \%)$ and post (58.13\%) emergence mortality was achieved when drenching was done with Bavistin while drenching with Topsin-M resulted in $55.00 \%$ pre emergence and $56.41 \%$ post emergence mortality at $0.4 \%$ concentration. The results achieved in the present investigation are in accordance with Sharma et al., (2004) who reported that Bavistin protected maximum pre emergence and post emergence mortality in Khejri afflicted by $F$. solani to the tune of 81.7 and $71.5 \%$, respectively followed by Topsin-M where the figures were 72.8 and $71.5 \%$, respectively.

In vivo evaluation of fungicides as combination of both seed dresser and soil drench: Any plant disease can be managed by following a package and practices, 
which may include cultural and chemical methods beside use of resistant material, plant extract and bioagents. However, in forest plantations, this task is more difficult as both pathogen and host exist without any break in time and space thus poses lot of problems. The management of disease by integration of various methods like seed treatment, soil drenching and foliar spray with fungicide was found effective in reducing the incidence of root rot of French bean caused by $F$. solani (Sharma and Gupta, 2003). In the present findings, integration of methods [seed treatment (ST) and soil drenching (SD)] showed a synergistic effect against root rot of Bael and the disease control efficiency increased as the concentration of fungicide was increased. Seed treatment and drenching with Bavistin could provide $72.51 \%$ disease control of preemergence mortality and $82.92 \%$ of post emergence mortality at $0.4 \%$ concentration. The values of disease control with Topsin-M were $68.75 \%$ in the former case and $80.36 \%$ in later. The efficacy of both the fungicides was more or less same. These results are in agreement with the observation made by Sharma et al., (2004). They advocated the supremacy of Bavistin and Topsin $\mathrm{M}$ in controlling root rot of Prosopis cineraria caused by $F$. solani.

Effect of bio-control agents on inhibition of radial growth of $F$. solani using dual culture technique: The role of antagonists in suppressing the growth of soil borne pathogens has been well documented (Garret, 1980). The present studies also proved the efficacy of $T$. harzianum and $T$. viride in inhibiting mycelial growth of $F$. solani in in vitro conditions as compared to P. maltophila, P. fluorescens and B. subtilis. The percentage inhibition by different antagonist ranged from 51 to $72 \%$. These observations fall in line with the findings of Bokhari and Kahkashan (2012). They found that in dual culture and volatile metabolites assays, T. harzianum was more effective in suppressing the growth (51.4 and $38.1 \%)$ of $F$. solani causing root rot of tomato. T. harzianum was found most effective against $F$. oxysporum attacking tomato as it resulted in maximum $(76.83 \%)$ growth inhibition reported by Jamwal et al., (2011).

Effect of bio-control agents on incidence of seedling mortality due to $F$. solani in Bael under screen house conditions: The biological control of soil borne pathogens by bio control agents have been amply stated (Weller, 1988). The recent development in the commercialization of bio-control products has accelerated this approach of disease management. Sain et al., (2005) reported that the bacterial bio-control agents increased plant growth indirectly by changing the microbial balance in the rhizosphere. The AM (arbuscular mycorrhizae) fungus $G$. mosseae was tried against $F$. solani individually and in combination with five antagonists viz., T. harzianum, T. viride, P. fluorescens, P. maltophilia and B. subtilis. The treated seeds were sown in already inoculated soil. The least, both pre and post emergence, mortality was recorded in combination treatment of $G$. mosseae $+T$. harzianum thereby provided 63.41 and $66.95 \%$ control of the two mortalities, respectively. G. mosseae $+T$. viride was adjudged second in order of efficacy. The values of pre and post emergence mortality in $G$. mosseae alone were 20.00 and $33.66 \%$. The studies are in complete agreement which revealed that combinations of $G$. mosseae $+T$. harzianum $+P$. fluorescens was superior to individual strains in reducing the Fusarium rhizome rot of ginger under green house conditions (Gupta et al., 2010).

\section{Conclusion}

The present investigation revealed that seed treatment and drenching with Bavistin could provide $72.51 \%$ disease control of pre-emergence mortality and $82.92 \%$ of post emergence mortality at $0.4 \%$ concentration. The values of disease control with Topsin-M were $68.75 \%$ in the former case and $80.36 \%$ in later. Glomus mosseae and Trichoderma harzianum should also be added to the soil for better results as 63.41 and $66.95 \%$ control of the pre-emergence mortality and post emergence mortality, respectively was provided by these two agents when used in combination. Hence, it can be concluded that mortality due to root rot in bael incited by $F$. solani can be checked by the integration of seed treatment with either Bavistin or Topsin $\mathrm{M}$ and pre-sowing drenching. G. mosseae and $T$. harzianum should also be added to the soil for better results.

\section{REFERENCES}

Aiyer, A.K.Y.U. (1956). The Antiquity of Some Field and Forest Flora of India. Bangalore Printing and Publishing Co. Ltd., Bangalore. 168 pp.

Anonymous (2011). Annual Report of AICRP on Arid Zone Fruits. CIAH, Bikaner, Rajasthan.

Bokhari, N.A. and Kahkashan, P. (2012). Antagonistic action of Trichoderma harzianum and Trichoderma viride against Fusarium solani causing root rot of tomato. African J. Microbio. Res. 44: 7193-7197.

Garret, S.D. (1980). Species of Trichoderma and Gliocladium as agents for biological control of root disease fungi. In: Recent Advances in the Biology of Microorganism, Bishen Singh and Mahender Pal Singh Publishers, Dehradun.

Gupta, Meenu, Dohroo, N.P. and Shanmugam, V. (2010). Effect of microbial inoculants on rhizome disease and growth parameters of ginger. Indian Phtopath. 63: 438441.

Jamwal, S., Jamwal, A. and Verma, V.S. (2011). Effect of biocontrol agents on wilt management and plant growth of tomato. Indian Phytopath. 64: 381-382.

John, L. and Stevenson, V. (1979). The Complete Book of Fruit. Anqus and Roberson Publications.

Khodke, S.W. and Raut, B.T. (2010). Management of root rot/collar rot of soybean. Indian Phytopath. 63: 298301 .

King, E.O., Ward, M.K. and Raney, D.E. (1954). Two simple media for the demonstration of pyocyanin and fluorescein. J. Lab.Clinical Med.. 44: 301-307. 
Kirtikar, K.R. and Basu, B.D. (1935). Indian medicinal plants. Vol-1 Published by L.M. Basu, Allahabad.

Kumar, S., Sharma, S., Pathak, D.V. and Beniwal, J. (2011). Integrated management of jatropha root rot caused by Rhizoctonia solani. J. Trop. For. Sci. 23: 35-41.

Kumar, S., Sharma, S., Saharan, H.S. and Deswal, R.P. (2012). Management of root rot of jatropha caused by Rhizoctonia bataticola with plant growth promoting rhizobacteria. Indian Forester. 138: 85.-852.

Margaret, W.M., Ethel, O.M., Sheila, A.O. and Joyce, M.J. (2011). Inoculation of tomato seedlings with Trichoderma harzianum and arbuscular mycorrhizal fungi and their effect on growth and control of wilt in tomato seedlings. Braz. J. Microbiol. 42: 34-38.

Morton, D.T. and Stroube, W.H. (1955). Antagonistic and stimulatory effects of microorganisms upon Sclerotium rolfsii. Phytopathology. 45: 419-420.

Palmiter, D.H. and Keith, G.W. (1937). The toxicity of copper lime arsenic mixture of certain phytopathogenic fungi as malt agar plate. J. Agric. Res. 55: 439-452.

Poddar, R.K., Singh, D.V. and Dubey, S.C. (2004). Management of chickpea wilt through combination of fungicides and bioagents. Indian Phytopath. 57: 39-43.

Ramesh, K.R. (2002). Control of collar rot of teak seedlings by some selected fungicides and biocontrol agents through soil application. Indian J. of Forestry. 25: 154157.

Sain, S.K., Gaur, H.N. and Sharma, P. (2005). Biocontrol of black rot of cauliflower by plant growth promoting rhizobacteria. J. Mycol. Pl. Pathol. 35: 99-102.

Sinha, A.P., Singh, Kishan and Mukhopadhyay, A.N. (1988). Soil Fungicides Vol. II, CRC Press, Florid, USA, 174 pp.

Sharma, Monica and Gupta, S.K. (2003). Ecofriendly methods for the management of root rot and web blight of French bean. J. Mycol. Pl. Pathol. 33: 345-361.

Sharma, S., Pal, R., Gupta, P.P. and Kaushik, J.C. (2004). Management studies on root rot of Prosopis cineraria caused by Fusarium solani. J. Trop. Forest Sci. 16: 71-77.

Sharma, S. and Gaur, R.K. (2014). Occurrence of root rot in Aegle marmelos - a new host record. The Indian Forester, 140: 203-204.

Vatchev, T. and Maneva, S. (2012). Chemical control of root rot complex and stem rot of green house cucumber in straw-bale culture. Crop Protection. 42: 16-23.

Vincent, J.M. (1947). Distortion of fungal hyphae in the presence of certain inhibitors. Nature. 159: 850.

Weller, D.M. (1988). Biological control of soil borne plant pathogens in the rhizosphere with bacteria. Ann. Rev. Phytopathol. 26: 379-407. 